\title{
Plant growth promoting bacteria and humic substances: crop promotion and mechanisms of action
}

\author{
Fábio Lopes Olivares ${ }^{1}$, Jader Galba Busato², Alessandra M. de Paula², Lívia da Silva Lima', \\ Natália Oliveira Aguiar ${ }^{1}$ and Luciano Pasqualoto Canellas ${ }^{{ }^{*}}$
}

\begin{abstract}
High-external input agriculture is one of the most disruptive human activities, which have been justified by the current economic paradigm due to high productivity and the need to feed a growing population. However, we are dangerously close to the edge of the planet resources and both hunger and food insecurity has increased. Limiting the use of non-renewable chemical fertilizers and pesticides, changing water management, enhancing diversity and considering the often-neglected social dimension of agriculture are the bases to other chemical and biological technologies to agriculture. Biological inputs can stimulate the substitution of chemical inputs without questioning the current fundaments or can be adopted as a turning point to intensify the harsh processes of transition to more environmental friendly agriculture. The debate is open and our contribution is to develop the scientific basis for biological inputs that, unlike soluble fertilizers and pesticides, depend on a number of factors for its success in promoting crop yield. In this review, we showed the results obtained with the combined use of diazotrophic endophytic bacteria and humic substances in diverse crops (sugarcane, maize, tomato, common beans and pineapple), presenting the main morphological and physiological changes induced by biological technology. A snapshot of the state of the art of the use of plant growth promoting bacteria together with humic substances was provided, showing their potential especially when plants are subjected to moderate to severe abiotic stress. The number of studies reporting the combined use of plant growth promoting bacteria and humic substances is surprisingly low. There is an open avenue for research and encouraging debate is the goal. To overcome the conventional agriculture, maintaining productivity levels is more than scientific challenge, is a humanitarian duty. The biological inputs can help in this purpose.
\end{abstract}

Keywords: Bacterial inoculants, Humic acids, Abiotic stress, Biostimulant, Sustainable agriculture

\section{Introduction}

Worldwide pesticide pollution, pest adaptation and resistance, loss of soil fertility and organic carbon, soil erosion, decreasing biodiversity, desertification, starving people in poor nations, increasing food prices [1] make conventional agriculture one of most disruptive human activities. But current economic paradigm kicks the can

\footnotetext{
${ }^{*}$ Correspondence: lucianocanellas@gmail.com

${ }^{1}$ Núcleo de Desenvolvimento de Insumos Biológicos para a Agricultura (NUDIBA), Universidade Estadual do Norte Fluminense Darcy Ribeiro (UENF), Av. Alberto Lamego, 2000, Campos dos Goytacazes, Rio de Janeiro 28013-602, Brazil

Full list of author information is available at the end of the article
}

down the road. The debate about how to overcome the negative consequences of this model of agriculture is open, but even economic arguments can be questioned by anyone. The trade balance of the peripheral economies is strongly dependent of the agricultural commodities and the production costs have an important role. Most part of the fertilizers and agrochemicals used in Brazil and others development countries are imported and quoted in dollars, reaching to the farmers with a high price. For example, urea has been sold at a price higher than US\$ 400 per ton, which is very expensive for the smallholder farmers. Simple like this: sovereignty and food security are dependent of the industrial fertilizers trade. Furthermore, the influence of fertilizers in the 
production costs is not small and reaches about 30\% [2]. In Brazil, the bigger agricultural country, the price of fertilizers increased by $37 \%$ in the 2015-2016 seasons growing compared to the previous agricultural year. Look this exemplary case considering the maize: in the last 5 years, the fertilizers increased near threefold while the price paid to the producer varied only $66 \%$ according to the Brazilian official harvest survey [2]. For us, in the tropical zone, it sounds very strange to hear that the application of chemical fertilizers is an inexpensive practice [3]. In addition, the main part of Brazil (and tropical countries) is covered by high weathered soils with low cation exchange capacity, cations nutrients removal by leaching process and consequently high acidity and aluminum toxicity [4]. In these conditions, you need a large amount of correctives of acidity and fertilizers which, in turn, has limited efficiency in these soil conditions. Thereby, economic reasons are moving sectors of traditional agriculture closer to those who do agriculture with less negative impact on the environment for socio-environmental reasons. Thereafter, increasing attention is being paid to the downside of high-input agricultural systems and much research is aimed at developing alternative ways to produce food, wood and plant for energy production in a sustainable and environmentally sound way [5].

Biological techniques are promising approach to enhance the efficiency of nutrient use, reducing the environmental and financial costs of agricultural production. The case of rhizobia/soybean in Brazil is an emblematic example of the biological inputs impact on economy and environment services. Over the years, the development of this technology allowed to abolish almost completely the need for nitrogen fertilizers application in the soybean crop. However, the main crops used to human food and bioenergy production are non-leguminous plants (rice, wheat, maize, sugarcane), i.e., non-nodulating species of plant growth promoting bacteria (PGPB) that colonize surface and interior of the plant tissues. In this case, epiphytic and endophytic PGPB can play a relevant role in the nutrient efficiency use through biofertilization and biostimulation mechanisms [6]. Plant growth-promoting bacteria (PGPB) are a diverse group of bacteria capable of promoting growth and yield of many crops as a result of several effects on host including wide variety of mechanisms such biological nitrogen fixation, phosphate solubilization, alleviation of abiotic stress, siderophore production, rhizosphere engineering, production of 1-aminocyclopropane-1-carboxylate deaminase (ACC), quorum sensing (QS) signal interference and inhibition of biofilm formation, phytohormone production, exhibiting antifungal activity, induction of systemic resistance, promoting beneficial plant-microbe symbioses and interference with pathogen toxin production [7]. The potential benefits of PGPB to promote plant growth is enormous and the global market for bio-inoculants is growing at an estimated rate of $\sim 10 \%$ per annum [8].

The number of PGPB used to bioinoculant formulation is relatively low considering the natural biodiversity. In a critical review about formulations used for producing inoculants for plants from 1998 to 2014, it was found [9] that around of 30 genera and 60 species already have been used including: Azospirillum genus (A. brasilense, A. lipoferum, A. amazonense, A. rugosum and A. zeae); Azotobacter genus (A. chroococcum, $A$. vinelandii and Azotobacter sp.); Bacillus genus (B. licheniformis, B. megaterium, B. mycoides, B. pumilus, B. polymyxa, B. subtilis and Bacillus sp.); Burkholderia genus (B. cepacia, $B$. pyrrocinia, B. phytofirmans, B. tropica and B. silvatlantica); Chlorella genus (C. vulgaris and C. sorokiniana); Herbaspirillum genus $(H$. seropedicae; $H$. rubrisubalbicans and $H$. frisingense); Pseudomonas genus (P. aeruginosa, $P$. corrugate, $P$. fluorescens, $P$. jessenii, $P$. putida, $P$. striata, $P$. alcaligenes, $P$. aureofaciens, $P$. chlororaphis, $P$. synxantha and Pseudomonas spp.); Pantoea genus ( $P$. agglomerans, P. dispersa and Pantoea sp.); Streptomycetes genus (S. griseoluteus, S. griseoviridis and Streptomycetes sp.); Coniochaeta ligniaria; Beijerinckia sp.; Brevibacillus brevis; Enterobacter cloacae; Gluconacetobacter diazotrophicus, Klebsiella pneumoniae, Lysobacter gummosus, Methylobacterium oryzae, Micrococcus sp., Mycobacterium phlei, Paenibacillus polymyxa, Pichia guilermondii, Raoultella terrigena, Rhodobacter capsulatus, Rhodococcus rhodochrous, Serratia plymuthica, Sinorhizobium meliloti, Sphingobacterium canadense, Stenotrophomonas maltophilia, Thiobacillus sp., and Acinetobacter calcoaceticus.

Nitrogen-fixing bacteria of the species Gluconacetobacter diazotrophicus, Herbaspirillum seropedicae, Herbaspirillum rubrisubalbicans and Burkholderia tropica have been isolated from genotypes of grass species in high numbers [10] and have been as a multispecies inoculant recommended for sugarcane [11]. All of these bacteria live inside of plant host, i.e., are diazotrophic endophytic bacteria (DEB). The feasibility of the inoculation using DEB in sugarcane grown in soils with low to medium levels of fertility was previously demonstrated [12]. It is important to emphasize here that in soil with high natural fertility or high rates application of nitrogen fertilizers, the results related to the increase of crop production may be levelled out or minimized by the large nutrient availability.

The adoption of this technology is far below the potential shown by scientific research. The scientific efforts are mainly concentrated on isolation and selection of plantbeneficial microorganisms and their further application in soil-plant system in controlled conditions [13] and 
little attention are dedicated to formulation procedures, delivering application and effectiveness under field conditions. Several vehicles for PGPB delivery to crops are used including ethylcellulose, modified starch, carboxymethylcellulose, corn starch, chitosan, alginate, polymeric inoculants, $\mathrm{EB}^{\mathrm{TM}}$ (mainly clay and wood particles), vermiculite, perlite, clay pellets, talc, activated carbon filters, torrefied grass fibers, turf, local soils, kaolin, clay minerals, loess soil, clay soils, poultry manure, and banana waste, wastewater sludge, lignin corn straw, wheat or oat bran, fibers from brewer's spent barley grain, grape bagasse, cork compost, peat, sugar, coir dust/coco peat, compost from different raw materials and vermicompost/ earthworm compost, lignite, charcoal, gum, residues of Azolla and sawdust. All these vehicles were listed by Bashan et al. (2014) in reference [9] and, curiously, humic substances are not directly mentioned.

Humic substances (HS) are the major component of soil, water and sediment organic matter and chemically can be depicted as a collection of diverse, relatively low molecular mass components of organic molecules forming dynamic associations stabilized by hydrophobic interactions and hydrogen bonds on the nanometer scale [14]. The procedure consisting in the sequential fractionation of humic domains into either aqueous or organo soluble components and final unextractable humic residue, followed by molecular characterization suggested that humic suprastructures in soil are arranged in multimolecular layer [15]. Furthermore, it was possible to conclude that HS are spatially arranged in descending order of polarity, meaning that highly polar supramolecular subunits shield less polar subunits against the free soil solution and form layers of descending polarity', i.e., free soil solution [16]. This organization can protect bacteria cells and labile organic molecules against degradation in the hydrophobic domain, as elegantly demonstrated [17, 18]. The presence of organic acids, like those produced by root exudation, can modify the supramolecular arrangement, releasing bioactive molecules which can affect plant growth. The enhancement of organic acids exudation by maize due to HS treatment were independently demonstrated $[19,20]$ and the cross-talk involving plant roots and humic matter was recently approached [21]. The physiological effects of HS is widely documented [22, 23] and summarized as a result of enhance nutrient use efficiency, aiding assimilation of both macro and micronutrients and promoting plant growth by induction of carbon, nitrogen, and secondary metabolism [21].

HS are relatively recalcitrant to bacteria degradation and affect rooting including induction of lateral root formation and root hair initiation. The anatomical and physiological changes may favor the fitness of the mutualistic interaction by increasing rhizosphere population and chemotaxis, bacteria attachment and survival on plant surface as well as endophytic colonization (Fig. 1).

For this and other physiological modifications, we indicate the HS as a candidate to suitable vehicle for PGPB. The aim of this work is to produce an overview on the papers published in peer-review journals at Scopus and Web of Science data base using PGPB in combination with HS as key-word. In the first part, we showed the main results obtained in the Nudiba (UENF), Brazil, followed by the description of some mechanisms that underline the success of the combination of DEB and HS. The main results are summarized in the graphical abstract. After, the state of the art of this biotechnology is presented. We intend to demonstrate at the end of this review that co-inoculation can be an excellent, but very little explored tool to aid crop production, especially under stress conditions (nutritional, saline or toxicity of some element).

\section{DEB and HS}

\section{Effects on sugarcane}

The first report using the approach considering the application of cell suspension of the DEB together with soluble HS at low concentration was in a sugarcane seed pieces [24]. This crop, in the north of Rio de Janeiro State, Brazil, has the endemic incidence of Leifsonia xyli subsp. $x y l i$, the causal agent of ratoon stunning disease, the main sugarcane crop disease [25]. The unique treatment, besides the introduction of sugarcane disease-resistance varieties, is the heat treatment which consists to subjecting seed pieces to a temperature of $50.5^{\circ} \mathrm{C}$ for $2 \mathrm{~h}$. As this procedure is not selective, there is a substantial drawback in the entire population of beneficial and harmful microbial after heat treatment, offering an opportunity to introduce selected microorganisms. The seed pieces after heat treatment were immersed for $12 \mathrm{~h}$ into a container filled with DEB $\left(10^{8}\right.$ cells $\mathrm{mL}^{-1}$ of Herbaspirillum seropedicae strain HRC54) and humic acids (HA) (20 mg C L ${ }^{-1)}$ isolated from vermicompost, transplanted to a pot containing $3 \mathrm{~kg}$ of substrate grown for 45 days. The main results were the root improvement (from 60 to $118 \%$, in length, and from 33 to $233 \%$, in surface area) by treatments compared to control, with more pronounced effect in plants under heat treatment. Likewise, the positive effect of the combined treatment (H. seropedicae and HA in suspension) on shoot and root biomass was significant compared to the control with heat-treated cuts. For heat-treated cuts, bacteria inoculation combined with $\mathrm{HA}$ increased the size of $H$. seropedicae population on roots. The practical limitations of this type of inoculation (after heat treatment) in Brazil are obvious considering its large scale production that reach almost nine millions of ha cultivated with sugarcane [2]. Hence, it was 
necessary to evaluate others forms of DEB-HA application and it was demonstrated a clear advantage of foliar application in respect to furrow [26]. The biostimulant manufactured with $\mathrm{K}^{+}$-humate isolated from vermicompost and $H$. seropedicae strain HRC54, $H$. rubrisubalbicans strain HCC103 and G. diazotrophicus strain PAL5 had shown better performance when was applied at 60 days after sugarcane emergence, enhancing 37\% of the stem yield when compared to control. The field assay using strip plot design with a large parcel area confirms the promotion of sugarcane yields by biostimulant during two consecutive ratoons increasing 19 and $18 \%$ of yield, representing 11 and 13 tons ha more than the control. In both experiments were not observed changes in the polarized sugar content and consequently the stems production is linearly related with sugar yields. A noticeable increase was observed in a year with severe drought stress occurrence showing the positive effect of the combined use on mitigation of abiotic stress damage. The field experimentation at commercial sugarcane plantation was accompanied by greenhouse experimentation where sugarcane was submitted to controlled drought stress and its recovery was evaluated [27]. The effect of biostimulant using the mixture of different DEB strains and HA suspension on shoot and root biomass was also observed in pot assay. The antioxidant enzymes superoxide dismutase, catalase and ascorbate peroxidase activities remained higher after rehydration only in plants treated with HA. Plants treated with only HA or DEB together with HA exhibited increased transpiration, stomatal conductance and net photosynthesis than the plants treated with DEB. The DEB-treated plants exhibited drought resistance that resembled 'delayed stress onset' mechanism, which is a term for preserving water in the plants tissues. Water preservation in plants treated with DEB was corroborated by higher relative water content than control plants at the end of the drought period. It was also observed an osmotic adjustment induce by the biostimulant treatment and indicated by a new pattern of metabolic response after rehydration, including generally enhanced carbohydrates and proteins and specific changes induced by HA-enhancing aromatic compounds, whereas DEB exhibited enhanced fatty acids and other aliphatic $\mathrm{H}$ species. The authors concluded that HA assist with drought stress recovery by inducing antioxidant enzyme activity, whereas DEB induced preservation of leaf water potential and relative water content by closing stomata efficiently, resulting in plant water preservation.

\section{How Humic acid modulate plant-bacteria interaction ?}

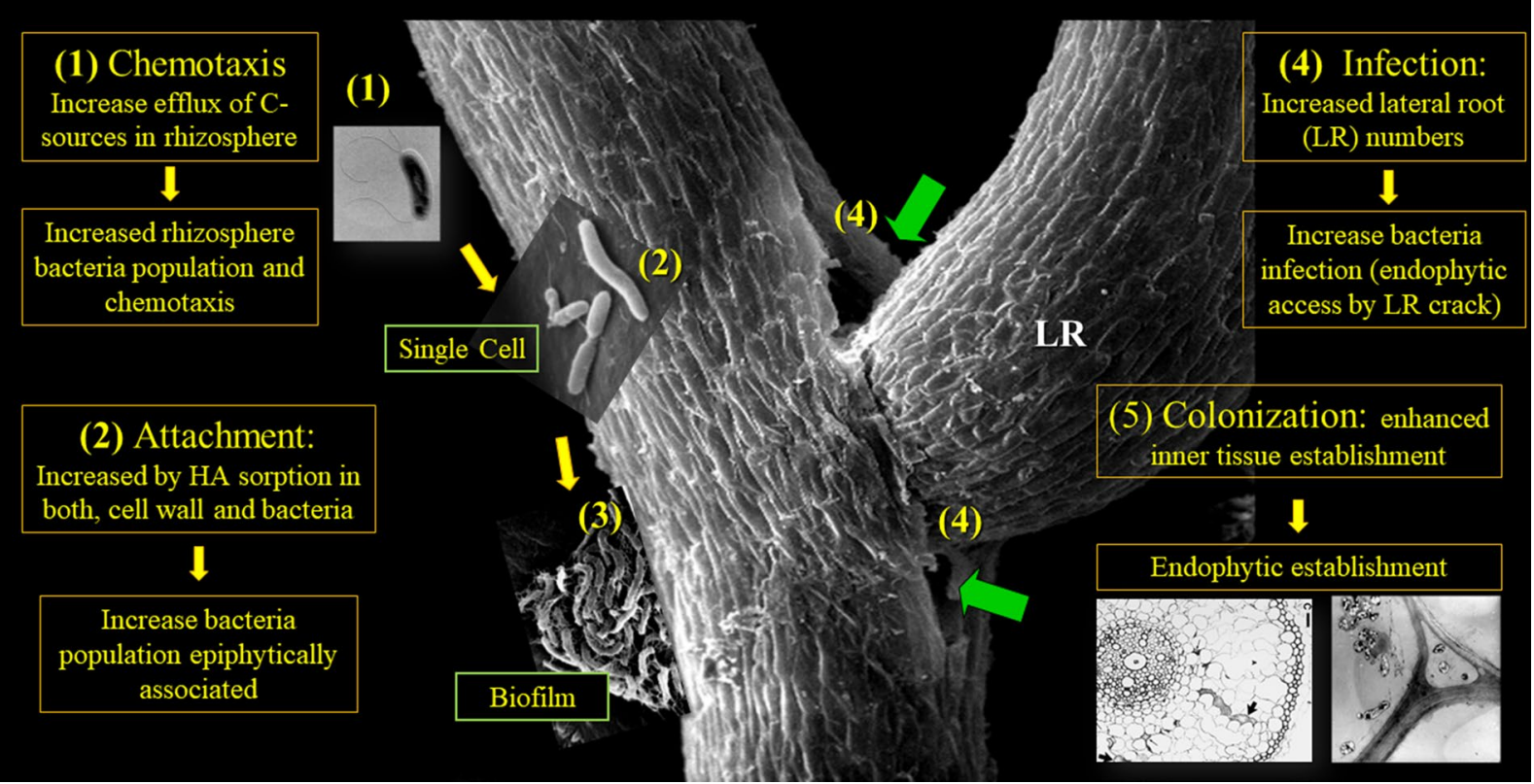

Fig. 1 Schematic representation of predominant events that characterize the endophytic interaction between diazotrophic bacteria and plant host: (1) chemotaxis from soil to rhizosphere; (2) attachment on plant root surface; (3) development of aggregates or biofilms; (4) lateral root cracks as main infection point and (5) apoplastic spread and endophytic colonization. Followed by how the application of humic acid combined with endophytic diazotrophic bacteria could modulate different steps of the biological interaction that results in increased epiphytic and endophytic population associated to the host plant 


\section{Effects on common beans}

The same qualitative results were obtained with common beans, that is greater recovery from water stress in plants co-inoculated with Rhizobium tropici strains 'BR322', 'BR520', and 'BR534 and H. seropedicae strain HRC 54 in the presence of HA [28]. Two independent experiments were conducted in a greenhouse using Phaseolus vulgaris cv. Grafite and cv. Bonus, which originated in Brazil and Mozambique, respectively. The soil humidity was maintained at field capacity in pots, and the water suppression was induced at the pre-flowering stage. After 12 days, the water was restored, and the beans were evaluated. In the experiment with 'Grafite' beans, the relative water content of the foliar disk was significantly higher in the coinoculated treatment, as were the numbers and masses of nodules. The phenylalanine ammonia lyase activity was induced by drought, and its activity was higher in co-inoculated plant leaves. The recuperation of the plants after water stress was clearly improved by the co-inoculation with rhizobia and $H$. seropedicae in the presence of HA-like substances.

\section{Effects on maize}

Coating maize seed with DEB and HA was previously reported [29]. The germination was not affected by seed coating that promoted root growth enhancing $44 \%$ the root length in respect to control. The number of diazotrophic bacteria cells was also increased from 2.4 to $6.7 \log ^{-1}$ cell per $\mathrm{g}$ of fresh root tissues (H. seropedicae strain $\mathrm{Z} 67=\mathrm{BR} 11175$ ). In that work, it was possible to observe that the treatment of seed coating only with HA also induce the increased native population of diazotrophs in the roots. This observation was corroborated when DEB and HA was used in maize seedlings in suspension $\left(2 \times 10^{9}\right.$ cell of $H$. seropedicae strain $\mathrm{Z} 67$ per $\mathrm{mL}$ plus $20 \mathrm{mg} \mathrm{C}$ of HA) [30]. The number of viable bacterial cells was higher in root tissues when the inoculation was in the presence of soluble humic substances. The physiological changes induced by co-inoculation was evaluated including enhancement of plasma membrane $\mathrm{H}^{+}$-ATPase activity, alteration of carbohydrate and nitrogen metabolism, and greater net photosynthesis. In the field experiment, the treatments were applied by foliar spray at v6 developmental stage and when DEB and HS were singly applied grain yield increased about $20 \%$ in respect to control plants while applied together the increase of yield reach $65 \%$. The soil used in this field experimentation was classified as Ultisol that showed low natural fertility $\left(\mathrm{CEC}<5 \mathrm{cmol}_{\mathrm{c}} \mathrm{kg}^{-1}\right.$ ) and were used low level of fertilizers $\left(50 \mathrm{~kg}\right.$ of $\left.\mathrm{N} \mathrm{ha}^{-1}\right)$. The level of maize yield is considered very low $\left(2800 \mathrm{~kg} \mathrm{ha}^{-1}\right)$ and typical from subsistence agriculture founded in the region where the experiment was conducted (Macaé,
Rio de Janeiro State, Brazil). However, the enhance promoted by one foliar application of biostimulant $\left(4480 \mathrm{~kg} \mathrm{ha}^{-1}\right)$ is enough to promote the food security for smallholders. We repeat the field experimentation in other place for two consecutive growth season using an Inceptisol also located in North of Rio de Janeiro State with medium level of natural fertility and varying the urea amount used in nitrogen fertilization at coverture $\left(0-200 \mathrm{~kg} \mathrm{~N} \mathrm{ha}^{-1}\right)$ [31]. The maize yield increased independently of urea doses in parcels with application of a combination of humic substances isolated from vermicompost at $50 \mathrm{mg} \mathrm{L}^{-1}$ and $H$. seropedicae strain HRC $54\left(5 \times 10^{8}\right.$ cells $\left.\mathrm{mL}^{-1}\right)$ at equivalent rate of $450 \mathrm{~L} \mathrm{ha}^{-1}$ and applied at v6 stage. In the second year of experimentation, the increase of grain yield promoted by co-inoculation was also significant, but only until $75 \mathrm{~kg} \mathrm{~N} \mathrm{ha}^{-1}$. At higher $\mathrm{N}$ concentrations no effect of inoculation was observed in a typical and known effect [5]. The main difference between this two growth seasons was that the first year was marked by a severe drought stress while in the second the rain season had normal precipitation. The co-inoculation effect in maize yield was accentuated in the drought stress event. It was also reported that when more lately the foliar spray application of DEB humic acids was done best results were achieved [31]. The original idea of seed covering or foliar application at plant seedlings (7-15 days old) has been superseded by later application. It was also observed that maize parcels inoculated with DEB and HS showed higher root systems left in the soil after harvest in a significant contribution to soil organic matter maintenance. This important environmental service almost is not counted and should be considered as a carbon sequestration strategy.

\section{Effects on tomatoes}

Other approach with significant results was when DEB and HS were used in a substrate to seedlings growth knowing as biofortification strategy. Tomato is one of the main horticulture plants in Brazil and we applied the DEB and HS in the commercial substrate or in the substrate manufactured with vermicompost naturally enriched with PGPB and humic matter with high biological activity [32]. The biofortification of the substrate boost the initial development of tomato seedlings and when transplanting to experimental field the gains obtained in the initial phase of plant development were maintained. The foliar spray application of DEB and HS promoted additional effect on fruit production and disease-resistance resulting in greater yield [32]. It was observed the enhancement of the $\mathrm{N}_{2}$-fixing population associated with rhizosphere soil, root and leaf tissues in the combined use of bacteria and humates by foliar spray. 


\section{Effects on pineapple}

The initial performance of tissue-cultured pineapple variety Vitória in response to application of $\mathrm{HA}$ isolated from vermicompost and PGPB (Burkholderia sp. UENF 114111 and Burkholderia silvatlantica strain UENF 117111) during greenhouse acclimatization was studied by Baldotto and colleagues [33]. The period of pineapple acclimatization is critical due to the low growth rate of roots and shoots. In this phase, structural and physiological adjustments of plantlets to ex vitro conditions are crucial for the success in the subsequent phase, i.e., field transplantation. The basal leaf axils were treated with HA while roots were immersed in bacterial medium, resulting in improved shoot growth (147\%). The isolated application of HA increased root growth by $50 \%$, bacteria by $81 \%$ and the combined treatment by $105 \%$. Pineapple growth was influenced by inoculation with both Burkholderia, and further improved in combination with humic acids, resulting in higher shoot and root biomass as well as nutrient contents (N 132\%, P 131\%, $\mathrm{K} 80 \%$ ) than in uninoculated plantlets. The stability and increased consistency of the host plant response to bacterization in the presence of HS indicate a promising biotechnological tool to improve growth and adaptation of pineapple plantlets to the ex-vitro environment.

We showed some examples of successful use of biotechnology process using DEB and HS as inoculant applied directly on different plants. Now, we intended to depict the main mechanisms responsible for the synergist effect observed in so different plants crops as sugarcane, maize, tomato, and pineapple with different growth and developmental phases and environmental conditions.

\section{Mechanisms responsible for the success of DEB and humic substances \\ Morphological adaptations}

Our previous laboratory and field experiments commented above were strictly based on well recognized endophytic bacteria as part of the biostimulant formulation combined with HS. This is important issue not always considered. According to the professor Günter Neumann [34], from the University of Hohenheim (Stuttgart, Germany), about $70 \%$ of field experiments using microorganisms as bio-effectors did not show significant results. The use of endophytic bacteria drives the interaction with the host plant forcing the bacteria to compete for infection sites. The successful entry into the host plant by endophytes is made through root tips, root cracks at the point of emergence of lateral roots, injured sites on the root epidermis, stomata apertures, and damaged trichomes. The most prominent morphological modification in plants induced by both HS and DEB includes the promotion of lateral roots emergence (Fig. 2A). The morphological changes of the root system triggered by HS comprise increases of lateral root formation sites, root hair density and length [21], as well as overall surface area available for bacteria attachment (Fig. 2B). We could expect an increase in the population size plant-associated coupled with humate since the number of openings due to the emergence of lateral roots increases (Fig. 2C). In addition, the extreme heterogeneity of the root and leave surface after the contact with soluble humic acids facilitates the anchoring of microorganisms (Fig. 2D) and for overall picture (see Fig. 1).

Controlling plant root architecture is a fundamental part of plant development enabling to respond environmental conditions changes. Variations in the surface area of plant root systems are brought about largely by variations in root branching [35]. Underpinning each stage of lateral roots development is the hormone auxin [36]. It is known that HS can simulating the behavior of plant hormones and the presence of indole acetic acid has been demonstrated using different approaches. The auxin-like effect of HS was confirmed by a molecular approach [37]. The auxin-like compounds produced by PGPB is also well known and often reported as a positive Salkowski reaction and HPLC [38].

Other important morphological adaptation in roots induced by HS and scarcely reported is on the border cells formation and release from tips [39]. Border cells constitute the first living boundary in plant-soil ecosystems and play an important role in environmental sensing and regulate the interaction of living microorganisms of the rhizosphere [39]. HA can modulate the border cell number and shape and the association of border cells with mucilage, which serves to protect these cells and enhance viability. In addition, micrographs showing the packaging of border cells were obtained at all HA concentrations used and are indicative of the spontaneous self-organization of humic particles in suspension. We demonstrate that HA at the root tip surface can increase $H$. seropedicae attachment, aggregation and root tip colonization, thus changing the natural behavior of the bacterial-plant interaction [38]. It is possible that adsorbed HA can change the density and increase the number of hydrophobic domains, or modulate border cells secretion pattern through HA induction or neutralization of the biosynthesis of chemoattractant/antimicrobial compounds which results in increased bacterial cell adhesion to root tips. According to Olivares and Canellas [38] observations, exogenous HA increased the bacterial population surrounding border cells.

The induction of lateral roots, the increase of surface roughness of leaves and roots and the protect packing by HS particles as important morphological changes that contributes to the PGPB population increase promoted by HS. 


\section{Physiological changes}

Although plant physiology is a very broad field of study, the first thing that comes to mind is related to the plant functioning including processes like photosynthesis, respiration, nutrient uptake, hormone control of development, stress adaption, plant water relationship among others. We started by exudation process since the infection process of $H$. seropedicae begins bacteria stimulation in rhizosphere coupled with their attraction to the roots. The host provides carbon sources for the bacteria. It was previously observed an increase of organic acids exudates into the rhizosphere of maize plants treated with HA $[18,19]$, which could be used as carbon substrate to support the bacteria population growth associated with the root system. Furthermore, one of the main mechanism of DEB to solubilize phosphorus is the efficient production of organic acids mainly oxalic, citric, succinic and ascorbic acids [40]. The significant efflux of organic anions in roots treated with humic acids was observed [41] Organic acids are one the main source of carbon to PGPB and the rhizodeposition of labile compounds induced by $\mathrm{HA}$ in the inoculation medium can attract the bacteria. Interestingly, the supramolecular structure disassembling by organic acid that was well reported, release bioactive compound that modulates root architecture and increase epiphytic and endophytic bacteria colonization. Hypothetically, such virtuous cycle has been established over the coevolution process involving organic matter-microorganism and plants and deciphering different aspects of this cross-talk represent a powerful tool to change agriculture paradigm.

Moreover, significant changes in root exudation profiles were induced by $H$. seropedicae and HA, including the increase on fatty acid exudation from seedlings treated only with HA and on nitrogenous compounds and terpenes from seedlings treated only with $H$. seropedicae [42]. Seedlings treated with $H$. seropedicae in combination with HA enhance the amount and diversity of nitrogenous compounds exuded, most of which had heterocyclic structures. These changes in the rhizosphere chemical nature can affect the bacteria attraction and favored the host colonization process. The chemical changes induced by HS and DEB in the rhizosphere have an important role in the cross-talk relationship among environment and root growth. The observed increase in the root surface induced by both DEB and HA can be linked with stimulation of plasma membrane $\mathrm{H}^{+}$-ATPase according the acid growth mechanisms induced by auxins and auxin-like compounds [43] present in the humic suprastructure or synthesized by DEB. $\mathrm{H}^{+}$-ATPase activation could also be mechanistically linked to the root hairs proliferation since it was demonstrated that cell growth depends on extracellular acidification in maize roots [44]. The DEB and HA-induced stimulation of the $\mathrm{H}^{+}$-ATPase activity [29] suggest that the modifications are not restricted to root architecture, but are also extended to major biochemical components. Indeed, the driving force for most nutrient uptake is the electrochemical gradient across the plasma membrane, which is primarily generated by the $\mathrm{H}^{+}$-ATPase. Previous report had shown that, in some circumstances, when bacteria gain entrance into the plant tissue, it could occur by cell wall-hydrolyzing enzymes that support the process of bacteria invasion and dissemination in the host [45]. These enzymes had increased activity under low $\mathrm{pH}$, which is compatible with $\mathrm{H}^{+}$-ATPase induction by $\mathrm{HS}$, which reinforce our hypothesis that HS can make the delivery process of the DEB more efficient to the host plant.

The main function of the plasma membrane $\mathrm{H}^{+}$ATPase is to generate a proton electrochemical gradient, thereby providing the driving force for the uptake and efflux of ions and metabolites across the plasma membrane [46]. Thus, it is not surprise that HA from vermicompost and Burkholderia spp., separately and even more when combined, promoted the growth of the aerial part, root system and increased the contents of $\mathrm{N}, \mathrm{P}, \mathrm{K}, \mathrm{Ca}$ and $\mathrm{Mg}$ in pineapple [32]. The enhancement of nutrient uptake is one of more significant effect of the co-inoculation in plants, especially nitrogen and phosphorus. The activities of enzymes linked to nitrogen assimilation in maize seedlings were promoted by the $H$. seropedicae and HA application [29]. The treatment combining H. seropedicae and different concentration of HS induced nitrate reductase (NR) activity in leaves between 120 and $230 \%$ in relation to the control. Nitrogen is the major limiting factor in plant growth and productivity, therefore it is of great importance to study the enzyme activity related to its assimilation. The NR enzyme, together with nitrite reductase, catalyze the two-step reduction of nitrate $\left(\mathrm{NO}_{3}{ }^{-}\right)$to ammonium $\left(\mathrm{NH}_{4}^{+}\right)$, which is rapidly incorporated into organic compounds through the activity of the enzyme glutamine synthase, which is also stimulated by co-inoculation. The carbohydrate metabolism was also changed by co-inoculation especially the decrease in the concentration of reducing sugar in leaves and interpreted as a metabolic intensification to nitrogen assimilation. Olivares and colleagues [31] also observed the modification on secondary metabolism in tomato co-inoculated with DEB and HA, including the enhance on the phenylalanine ammonia lyase (PAL) activity. The first evidence that HA can modify PAL activity in maize was provided by Schiavon et al. [47] and Ertani et al. [48]. This enzyme catalyzes the first committed step in the biosynthesis of phenolics by converting phenylalanine to trans-cinnamic acid and tyrosine to p-coumaric acid. Phenolic compounds are used by plants in a several mechanisms of defense 

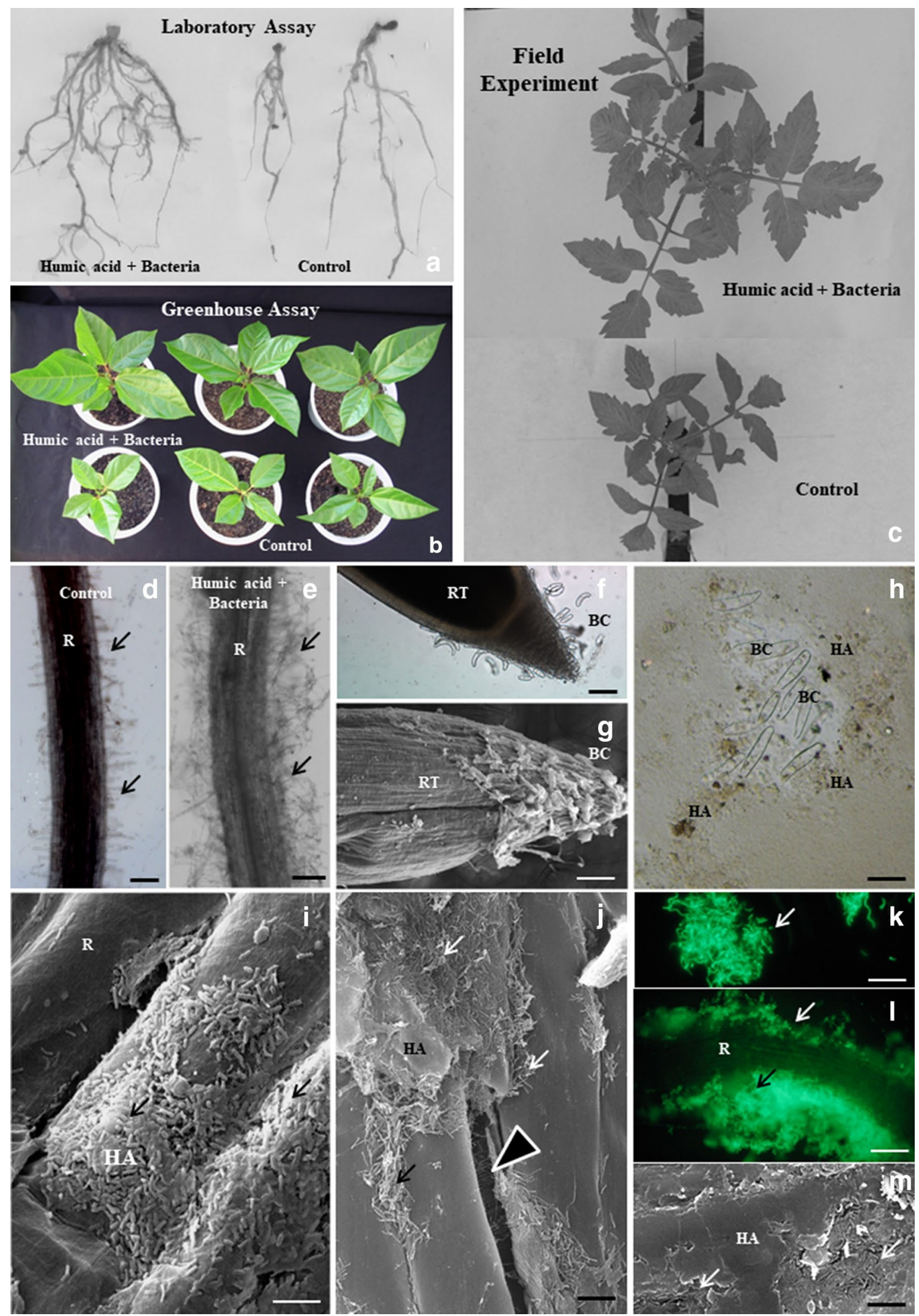
(See figure on previous page.)

Fig. 2 Basic and applied aspects related to the biological input designed with combined use of diazotrophic endophytic bacteria (DEB) and humic acid (HA). A-C Showing positives effect of the technology on root branching, root biomass and shoot biomass from lab to field experiments. D, E Light microscopy (LM) of maize root segments (R) comparing treated plants (DEB + HA) against mock plants. Note clear increase in density and length of root hairs (arrows). $\mathbf{F} L M$ from maize root tip (RT) showing border cells (BC) released trigged by HA. G Scanning electron microscopy (SEM) from the maize root tip (RT) showing root cap eroded by released border cells (BC). $\mathbf{H} L M$ from released border cells (BC) encapsulated by selforganized humic particles in suspension (HA). I SEM from maize root (R) surface colonized by Herbaspirillum seropedicae strain HRC54 aggregates in association with humic acid particles. J SEM from maize root surface close to the region of a lateral root emerged. Note crack developed in the epidermal layer (arrow head) and H. seropedicae strain HRC54 attached to the surface close to the entrance point (white arrows). K Epifluorescent microscopy (EM) of $\mathrm{H}$. seropedicae strain RAM 10 linked with a green fluorescent protein marker (arrow) forming a cluster around to a humic acid particle. L EM of a maize root segment colonized by a very active H. seropedicae strain RAM 10 biofilm (arrows). M SEM of humic acid (HA) plates associated with H. seropedicae strain HRC54 attached to the sugarcane leaf surface after foliar spray. Bar equal 100, 100, 200, 200, 50, 5, 5, 10, 150 and $20 \mu \mathrm{M}$, respectively, for D-M

including osmoprotection, UV scavenging and activation of defense pathway against biotic harmful agents.

Finally, it is possible return and extend the conclusion of Nardi and colleagues [21] saying that plant co-inoculation with DEB and HS, besides induction of lateral root formation and root hair initiation, enhance nutrient use efficiency, aiding assimilation and promoting plant growth by the induction of carbon, nitrogen, and secondary metabolism.

\section{PGPB + HS: why is it so little explored?}

We search for another results including DEB and HA and we did not find a vast literature. The main bacteria used in association with $\mathrm{HS}$ are free living microorganisms that need to compete at rhizosphere level for survival. Soil being a heterogeneous, unpredictable environment, the inoculated bacteria must to overcome complex biotic and abiotic impairing factors to establish a niche for survival amongst the competitors and predators [49]. Very few studies have been considering the effect of HS as a carrier that promotes PGPB fitness in the soil-rhizosphereplant continuum system. Table 1 summarizes the twelve reports founded in the database from two giants of scientific publishers (Web of Sciences from Thompson Reuters and Scopus from Elsevier). This is very little considering the potential of biological inputs and inoculation technology in the modern agriculture either in the processes of chemical inputs substitution, or in the adaptation to new technologies of production or even of ecological intensification. One possibility for explain this low number may lie in our fragmented way of doing research. Despite humus is a direct product of microbiological activity, the soil chemistry and soil microbiology have established faint scientific connections around the world. Increase in the sustainable intensification of agriculture is important developments towards new ways of training future scientist $[50,51]$. Inter-disciplinarily and boundary-crossing in terminology and concepts are needed. The use of these products in commercial crops also seems limited. It is necessary also point to the fact that the answers waited results from biological mechanisms, with an action also dependent on the conditions of the growing environment. However, some agricultural areas are present in degradation conditions so deep that it is necessary, first and foremost, to recover them using reconstruction minimum levels of fertility and soil organic matter content prior start the use of biostimulants. One of the first questions that researchers who employ biological products hear from farmers is: is this product efficient? As, in general, the farmer demands for immediate results, this may cause frustration. Although important, this is not the focus of this work and we return to Table 1.

The combined used of PGPB and HS was used to (i) promote crop production, (ii) mitigation of plant stress effect and (iii) microorganism protection. When applied directly to plants, the crop promotion was attributed mainly due enhance of nutrient efficiency use [52-58]. Schoebitz and colleagues [53] reported the use of consortium of very diverse microorganisms combined (or not) with K-humate. The growth of blueberry and $\mathrm{N}$ and $\mathrm{K}$ uptake increased and the authors find a very interesting and significant change on the bacterial structure community at rhizosphere when HA was used. Previously, this kind of change on bacteria diversity at maize rhizosphere induced by HA presence [51] opening a wide avenue to study changes in the microbiota and the interaction of these microbiota changes with crop productivity. Two papers found no significant differences on yield by PGPB and HS treatments $[55,56]$. Working with five different $\mathrm{N}$ concentration at field, it was found increase on wheat leaves, but not in grain yield [59] and when PGPB and HA was applied directly to soil it was observed significant increase on soil $\mathrm{P}$ availability, but without increase of soybean yield [60].

Two independent papers using very diverse type of plants found qualitative similar results when PGPB and HA were used under saline conditions [61, 62]. In the first report, the mitigation of salinity effects was 


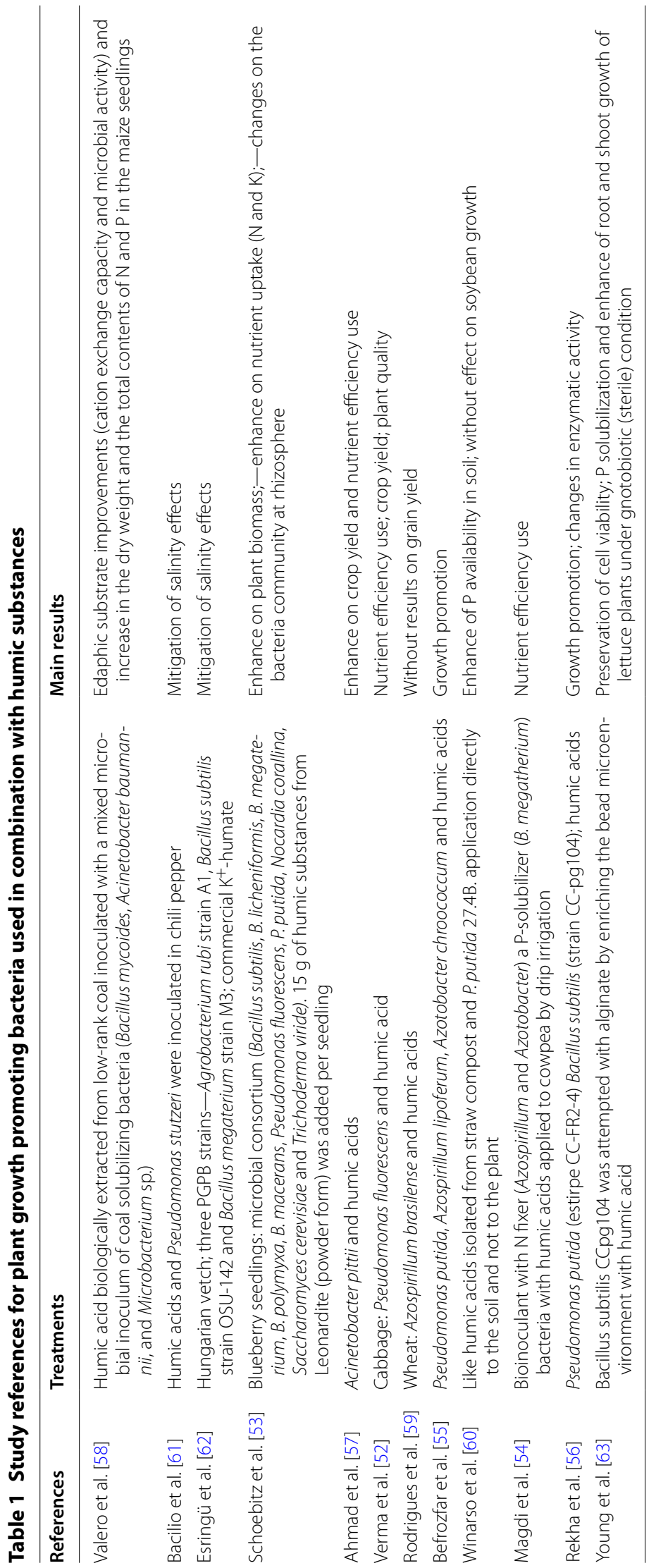


attributed due improvements in $\mathrm{K}^{+} / \mathrm{Na}^{+}$and $\mathrm{Ca}^{2+} / \mathrm{Na}^{+}$ ratios by chili peppers under inoculation with $\mathrm{Pseu}$ domonas stutzeri or HA treatment [61]. Changes in the ionic balance is the first and fast plant adaptation against stress including due promoted by high $\mathrm{Na}^{+}$concentration. The increase on $\mathrm{H}^{+}$-ATPase activity induced by $\mathrm{HS}$ is well reported and necessary to energize $\mathrm{K}^{+}$and $\mathrm{Ca}^{2+}$ transporters. The other paper where the effect of salinity was observed in Hungarian Vetch and the mitigation was attributed to promotion of plant growth parameters [62]. Finally, we would like to do mention to the work of Young et al. published in 2006 [63] where the authors proposed the encapsulation of PGPB Bacillus subtilis CCpg104 in alginate enriched with HA. The inoculation of encapsulated PGPB-HA enhanced the growth of lettuce under gnotobiotic (sterile) condition in respect to control (noinoculated) but the differences were not significant compared with non-encapsulated inoculation. However, the time of cell viability was larger in the encapsulated PGPB offer promising alternatives to increase the shelf-life of the inoculant and increase the protection against the deleterious effects of soil environment after delivering.

\section{Conclusion}

Overall agriculture's finger print is already immense. Struik and co-authors summarizing wrote [64, 65]:

"The societal costs of current ways of using technology for producing food also are substantial. From an agronomic and environmental perspective these include depletion and spillage of resources such as water, degradation of agro-ecosystems and natural ecosystems, decline in ecosystem services, loss of biodiversity, emission of greenhouse gases and toxic waste, post-harvest loss, among others, all contributing to agriculture's ecological footprint".

We agree with assumption that solutions for food security must be holistic and must address issues such as food accessibility that filling the lack of attention to justice [64]. Furthermore, the role of biological inputs in this debate also should be questioned, including the concept that this type of technology is primitive and backward. Here, we reported the results and expose the main action mechanism of biostimulant manufactured with diazotrophic endophytic bacteria mixed with HS used to enhance crop yield. The main benefit observed is the possibility of reducing the level of nutrients maintaining the level of production, in addition to mitigate the effects of different types of stress. The numbers of scientific reports considering the terms "plant growth promoting bacteria + humic substances" is very low considering the huge potential of this kind of biological inputs.

\section{Authors' contributions}

LPC and FLO wrote the first draft of the manuscript and took care of the revisions of the review; JGB, AMP, LSL and NOA contributed to the section PGPB + humic substances: why is it so little explored? All authors read and approved the final manuscript.

\section{Author details}

${ }^{1}$ Núcleo de Desenvolvimento de Insumos Biológicos para a Agricultura (NUDIBA), Universidade Estadual do Norte Fluminense Darcy Ribeiro (UENF), Av. Alberto Lamego, 2000, Campos dos Goytacazes, Rio de Janeiro 28013-602, Brazil. ${ }^{2}$ Faculdade de Agronomia e Medicina Veterinária, Universidade de Brasília, Campus Universitário Darcy Ribeiro, Caixa Postal 4508, CEP 70910-970 Brasília, DF, Brazil.

\section{Competing interests}

The authors declare that they have no competing interests.

Availability of data and materials

Other data and materials could be requested from the corresponding author.

\section{Consent for publication}

The authors agreed to the publication of the manuscript in this journal.

\section{Ethics approval and consent to participate}

This manuscript is an original paper and has not been published in other journals. The authors agreed to keep the copyright rule.

\section{Funding}

The work in NUDIBA laboratory (UENF, Brazil) was supported by Conselho Nacional de Desenvolvimento Científico e Tecnológico (CNPq), Fundação de Amparo à Pesquisa do Estado do Rio de Janeiro (FAPERJ), Instituto Nacional de Ciência e Tecnologia (INCT) para a Fixação Biológica de Nitrogênio and International Foundation of Science (IFS).

\section{Publisher's Note}

Springer Nature remains neutral with regard to jurisdictional claims in published maps and institutional affiliations.

Received: 11 October 2017 Accepted: 30 November 2017

Published online: 08 December 2017

\section{References}

1. Lichfouse E, Navarrete M, Debaeke P, Souchre V, Alberola C. Agronomy for sustainable agriculture: a review. Agron Sustain Agric. 2009;29:1-6.

2. Conab (Companhia Nacional de Abastecimento) web site with methodology and results of agriculture production costs. http://www.conab.gov. br/conteudos.php?a=1546\&t. Accessed Aug 2017

3. Halpern M, Bar-Tal A, Ofek M, Minz D, Muller T, Yermiyahu U. The use of biostimulants for enhancing nutrient uptake. In: Sparks DL, editor. Adv Agron; 2015. p. 141-74.

4. Camargo MN, Jacomine PKT, Carvalho APJ, Olmos IL. The Brazilian classification of Latosols. In: International soil classification workshop: classification, characterization and utilization of oxisols, EMBRAPA, SMSS, AID, UPR, Rio de Janeiro, Brazil. 1988. p. 190-202.

5. Thonar C, Lekfeldt JDS, Cozzolino V, Kundel D, Kulhánek M, Mosimann C, Neumann G, Piccolo A, Symanczik S, Walder F. Potential of three microbial bio-effectors to promote maize growth and nutrient acquisition from alternative phosphorous fertilizers in contrasting soils. Chem Biol Technol Agric. 2017;4:7.

6. Adesemoye AO, Torbert HA, Kloepper JW. Plant growth-promoting rhizobacteria allow reduced application rates of chemical fertilizers. Microb Ecol. 2009;58:921-9.

7. Bhattacharyya PN, Jha DK. Plant growth promoting rhizobacteria (PGPR): emergence in agriculture. World J Microbiol Biotechnol. 2012;28:1327-50.

8. Owen D, Williams AP, Griffith GW, Withers PJA. Use of commercial bioinoculants to increase agricultural production through improved phosphorus acquisition. Appl Soil Ecol. 2015;86:41-54. 
9. Bashan Y, de Bashan LE, Prabhu SR, Hernandez JP. Advances in plant growth promoting bacterial inoculant technology: formulations and practical perspectives (1998-2013). Plant Soil. 2014;378:1-33.

10. Döbereiner J, Baldani VLD, Reis VM. Endophytic occurrence of diazotrophic bacteria in non-leguminous crops. In: Vanderleyden J, Zamaroczy M, del Gallo FM, editors. Azospirillum VI and related microorganisms. Berlin: Springer; 1995. p. 3-14.

11. Embrapa. https://www.embrapa.br/en/busca-de-produtos-processose-servicos/-/produto-servico/550/estirpes-de-bacterias-fixadoras-denitrogenio-para-inoculacao-em-cana-de-acucar.

12. Oliveira ALM, Canuto EL, Urquiaga S, Reis VM, Baldani II. Yield of micropropagated sugarcane varieties in different soil types following inoculation with diazotrophic bacteria. Plant Soil. 2006;284:23-32.

13. Vassilev N, Vassileva M, Lopez A, Martos V, Reyes A, Maksimovic I, Löbermann B, Malusà E. Unexploited potential of some biotechnological techniques for biofertilizer production and formulation. Appl Microbiol Biotechnol. 2015;99:4983-96.

14. Piccolo A. The supramolecular structure of humic substances: a novel understanding of humus chemistry and implications in soil science. Adv Agron. 2002;75:57-134.

15. Drosos M, Nebbioso A, Mazzei P, Vinci G, Spaccini R, Piccolo A. Molecular zoom into soil Humeome by a direct sequential chemical fractionation of soil. Sci Total Environ. 2017;586:807-16.

16. Fischer T. Humic supramolecular structures have polar surfaces and unpolar cores in native soil. Chemosphere. 2017;183:437-43.

17. Spaccini R, Piccolo A, Haberhauer G, Gerzabek MH. Transformation of organic matter from maize residues into labile and humic fractions of three European soils as revealed by $13 \mathrm{C}$ distribution and CPMAS-NMR spectra. Eur J Soil Sci. 2000;51:583-94.

18. Spaccini R, Piccolo A, Conte P, Haberhauer G, Gerzabek MH. Increased soil organic carbon sequestration through hydrophobic protection by humic substances. Soil Biol Biochem. 2002;34:1839-51.

19. Canellas LP, Teixeira Junior LRL, Dobbss LB, Silva CA, Medici LO, Zandonadi DB, Façanha AR. Humic acids cross interactions with root and organicacids. Ann Appl Biol. 2008;153:157-66.

20. Puglisi E, Fragoulis G, Del Re AA, Spaccini R, Piccolo A, Gigliotti G, SaidPullicino D, Trevisan M. Carbon deposition in soil rhizosphere following amendments with compost and its soluble fractions, as evaluated by combined soil-plant rhizobox and reporter gene systems. Chemosphere. 2008:73:1292-9.

21. Nardi S, Ertani A, Ornella F. Soil root crosstalking: the role of humic substances. J Plant Nutr Soil Sci. 2017;180:5-13.

22. Nardi S, Carletti P, Pizzeghello D, Muscolo A. Biological activities of humic substances. In: Senesi N, Xing B, Huang PM, editors. Biophysico-chemical processes involving natural nonliving organic matter in environmental systems. Hoboken: Wiley; 2009. p. 305-39.

23. Canellas LP, Olivares FL. Physiological responses to humic substances as plant growth promoter. Chem Biol Technol Agric. 2014;1:3.

24. Marques Júnior RB, Canellas LP, Silva LG, Olivares FL. Rooting of micro seed pieces by combined use of humic substances and endophytic diazotrophic bacteria in sugar cane. R Bras Ci Solo. 2008;32:1121-8.

25. Carneiro JB Jr, Silveira SFS, Souza Filho GA, Olivares FL, Giglioti EA. Especificidade de anti-soro policlonal à Leifsonia xyli subsp. Xyli. Fitopatol Bras. 2004;29:614-9.

26. Silva SF, Olivares FL, Canellas LP. The biostimulant manufactured using diazotrophic endophytic bacteria and humates is effective to increase sugarcane yield. Chem Biol Technol Agric. 2017;4:24.

27. Aguiar NO, Medici LO, Olivares FL, Dobbss LB, TorresNetto A, Silva SF, Novotny EH, Canellas LP. Metabolic profile and antioxidant responses during drought stress recovery in sugarcane treated with humic acids and endophytic diazotrophic bacteria. Ann Appl Biol. 2016;168:203-13.

28. da Piedade Melo A, Olivares FL, Médici LO, Torres-Neto A, Dobbss LB, Canellas LP. Mixed rhizobia and Herbaspirillum seropedicae inoculations with humic acid-like substances improve water-stress recovery in common beans. Chem Biol Technol Agric. 2017;4:6.

29. Conceição PM, Vieira HD, Canellas LP, Marques-Júnior RB, Olivares FL. Recobrimento de sementes de milho com ácidos húmicos e bactérias diazotróficas endofíticas. Pesq Agropec Bras. 2008;43:545-8.

30. Canellas LP, Martínez-Balmori D, Médici LO, Aguiar NO, Campostrini E, Rosa RC, Façanha A, Olivares FL. A combination of humic substances and
Herbaspirillum seropedicae inoculation enhances the growth of maize (Zea mays L.). Plant Soil. 2013;366:119-32.

31. Canellas LP, Silva SF, Olk D, Olivares FL. Foliar application of Herbaspirillum seropedicae and humic acid increase maize yields. J Food Agric Environ. 2015;13:146-53.

32. Olivares FL, Aguiar NO, Rosa RCC, Canellas LP. Substrate biofortification in combination with foliar sprays of plant growth promoting bacteria and humic substances boosts production of organic tomatoes. Sci Hortic. 2015;183:100-8.

33. Baldotto LBE, Baldotto MA, Canellas LP, Bressan-Smith R, Olivares FL. Growth promotion of pineapple 'Vitória' by humic acids and Burkholderia spp. during acclimatization. R Bras Ci Solo. 2010;34:1593-600.

34. Neumann G. Perspectives and limitations for the use of BIOEFFECTORS in crop production. Oral Lecture at Summer School "Organic matter and Biological Agriculture" 3-6 July 2017 Lecture hall 8, Department of Agricultural Sciences (DIA), Università degli Studi di Napoli FEDERICO II Via Università 100, 80055-Portici. http://www.carbonfarm.eu.

35. Nibau C, Gibbs DJ, Coates JC. Branching out in new directions: the control of root architecture by lateral root formation. New Phytol. 2008;179:595-614

36. Casimiro I, Beeckman T, Graham N, Bhalerao R, Zhang H, Casero P, Sandberg G, Bennett MJ. Dissecting Arabidopsis lateral root development. Trends Plant Sci. 2003;8:165-71.

37. Trevisan S, Botton A, Vaccaro S, Vezzaroa A, Quaggiotti S, Nardia S. Humic substances affect Arabidopsis physiology by altering the expression of genes involved in primary metabolism, growth and development. Environ Exp Bot. 2011;74:45-55.

38. Frankenberger WT Jr, Arshad M. Phytohormones in soils: microbial production and function. New York: Marcel Dekker, Inc; 1995.

39. Canellas LP, Olivares FL. Production of border cells and colonization of maize root tips by Herbaspirillum seropedicae are modulated by humic acid. Plant Soil. 2017:417:403-13.

40. Driouch A, Cannesan MA, Dardelle F, Durand C, Plancot B, Brnard S, Follet-Gueye ML, Vicré-Gibouin M. Unit is strength: the power of border cells and border-like cells in relation with plant defense. In: Vivanco JM, Baluska F, editors. Secretions and exudates in biological systems signaling and communication in plants. Berlin: Spring; 2012. p. 91-108.

41. Busato JG, Lima LS, Aguiar NO, Canellas LP, Olivares FL. Changes in labile phosphorus forms during maturation of vermicompost enriched with phosphorus-solubilizing and diazotrophic bacteria. Bioresour Technol. 2012;110:390-5.

42. Ramos AC, Olivares FL, Silva LS, Aguiar NO, Canellas LP. Humic matter elicits proton and calcium fluxes and signaling dependent on $\mathrm{Ca}^{2+}$-dependent protein kinase (CDPK) at early stages of lateral plant root development. Chem Biol Technol Agric. 2015;1:1-12.

43. Lima LS, Olivares FL, Oliveira RR, Vega MRG, Aguiar NO, Canellas LP. Root exudate profiling of maize seedlings inoculated with Herbaspirillum seropedicae and humic acids. Chem Biol Technol Agric. 2014;1:23.

44. Rayle DL, Cleland RE. The acid growth theory of auxin-induced cell elongation is alive and well. Plant Physiol. 1992;99:1271-4.

45. Peters WS, Felle HH. The correlation of profiles of surface $\mathrm{pH}$ and elongation growth in maize roots. Plant Physiol. 1999;121:905-12.

46. James EK, Olivares FL. Infection and colonization of sugarcane and other graminaceous plants by endophytic diazotrophs. Crit Rev Plant Sci. 1998:17:77-119.

47. Schiavon M, Pizzeghello D, Muscolo A, Vaccaro S, Francioso O, Nardi S. High molecular size humic substances enhance phenylpropanoid metabolism in maize (Zea mays L.). J Chem Ecol. 2010;36:662-9.

48. Ertani A, Schiavon M, Altissimo A, Franceschi A, Nardi S. Phenol-containing organic substances stimulate phenylpropanoid metabolism in Zea mays. J Plant Nutr Soil Sci. 2011;174:496-503.

49. Lucy M, Reed E, Glick BR. Applications of free living plant growth promoting rhizobacteria. Antonie Leeuwenhoek. 2004;86:1-25.

50. Struik PC, Kuyper TW. Sustainable intensification in agriculture: the richer shade of green: a review. Agron Sustain Dev. 2017;37:39.

51. Puglisi E, Pascazio S, Suciu N, Cattani I, Fait G, Spaccini R, Crecchio C, Piccolo A, Trevisan M. Rhizosphere microbial diversity as influenced by humic substance amendments and chemical composition of rhizodeposits. J Geochem Explor. 2013;129:82-94. 
52. Verma R, Maurya BR, Meena VS. Integrated effect of bio-organics with chemical fertilizer on growth, yield and quality of cabbage (Brassica oleracea var capitata). Indian J Agric Sci. 2014;84:914-8.

53. Schoebitz M, López MD, Serrí H, Martínez O, Zagal E. Combined application of microbial consortium and humic substances to improve the growth performance of blueberry seedlings. J Soil Sci Plant Nutr. 2016;16:1010-23.

54. Magdi TA, Selim EM, El-Ghamry AM. Integrated effect of bio and mineral fertilizers and humic substances on growth, yield and nutrients contents of fertigated cowpea (Vigna unguiculata L.) grown on sandy soils. J Agron. 2011:10:34-9.

55. Befrozfar MR, Habibi D, Asgharzadeh A, Sadeghi-Shoae M, Tookalloo MR. Vermicompost, plant growth promoting bacteria and humic acid can affect the growth and essence of basil (Ocimum basilicum L.). Ann Biol Res. 2013;4:8-12.

56. Rekha PD, Lai WA, Arun AB, Young CC. Effect of free and encapsulated Pseudomonas putida CC-FR2-4 and Bacillus subtilis CC-pg104 on plant growth under gnotobiotic conditions. Bioresour Technol. 2007;98:447-51.

57. Ahmad S, Daur I, Al-Solaimani SG, Mahmood S, Bakhashwain AA, Madkour MH, Yasir M. Effect of rhizobacteria inoculation and humic acid application on canola (Brassica Napus L.) Crop. Pak J Bot. 2016;48:2109-20.

58. Valero N, Melgarejo LM, Ramírez R. Effect of low-rank coal inoculated with coal solubilizing bacteria on edaphic materials used in post-coalmining land reclamation: a greenhouse trial. Chem Biol Technol Agric 2016;3(1):1-10
59. Rodrigues LFSO, Guimarães VF, Silva MB, Pinto Junior AS, Klein J, Costa ACPR. Características agronômicas do trigo em função de Azospirillum brasilense, ácidos húmicos e nitrogênio em casa de vegetação. Rev Bras Eng Agríc Amb. 2014;18:31-7.

60. Winarso S, Didik SD, Handayanto E. Effects of humic compounds and phosphate solubilizing bacteria on phosphorus availability in an acid soil. J Ecol Nat Environ. 2011;3:232-40.

61. Bacilio M, Moreno M, Bashan Y. Mitigation of negative effects of progressive soil salinity gradients by application of humic acids and inoculation with Pseudomonas stutzeri in a salt-tolerant and a salt-susceptible pepper. Appl Soil Ecol. 2016;107:394-404.

62. Esringü A, Kaynar D, Turan M, Ercisli S. Ameliorative effect of humic acid and plant growth-promoting rhizobacteria (PGPR) on Hungarian vetch plants under salinity stress. Commun Soil Sci Plant Anal. 2016;47:602-18.

63. Young CC, Rekha PD, Lai WA, Arun AB. Encapsulation of plant growth-promoting bacteria in alginate beads enriched with humic acid. Biotechnol Bioeng. 2006;95:73-86.

64. Struik PC, Kuyper TW, Brussaard L, Leeuwis C. Deconstructing and unpacking scientific controversies in intensification and sustainability: why the tensions in concepts and values? Curr Opin Environ Sustain. 2014;8:80-8.

65. Loos J, Abson DJ, Chappell MJ, Hanspach J, Mikulcak F, Tichit M, Fischer J. Putting meaning back into "sustainable intensification". Front Ecol Environ. 2014;2:356-61.

\section{Submit your manuscript to a SpringerOpen ${ }^{\odot}$ journal and benefit from:}

- Convenient online submission

- Rigorous peer review

- Open access: articles freely available online

- High visibility within the field

- Retaining the copyright to your article

Submit your next manuscript at $\gg$ springeropen.com 